\title{
Evaluation of Belgian clays for manufacturing compressed earth blocks
}

\author{
Lavie A. MANGO-ITULAMYA ${ }^{1 *}$, Frédéric COLLIN² ${ }^{2}$ Pascal PILATE ${ }^{3}$, Fabienne COURTEJOIE ${ }^{4}$ \& Nathalie FAGEL ${ }^{1}$.
}

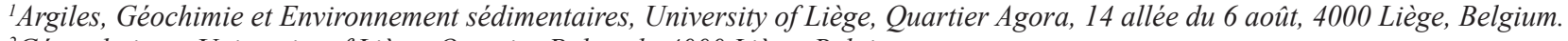 \\ ${ }^{2}$ Géotechnique, University of Liège, Quartier Polytech, 4000 Liège, Belgium. \\ ${ }^{3}$ Belgian Ceramic Research Centre, 4 Av. du Gouverneur E. Cornez, 7000 Mons, Belgium. \\ ${ }^{4}$ Architecture, University of Liège, 41 Boulevard de la Constitution, 4020 Liège, Belgium. \\ * corresponding author: mangoarsene@gmail.com.
}

\begin{abstract}
This study aims to characterize Belgian clays in order to evaluate their use for manufacture of compressed earth blocks (CEB). Nineteen Belgian clay deposits were sampled in 56 sites and 135 samples were collected and analyzed. The analyses focus on the determination of particle size, plasticity, nature and mineralogy as the main characteristics for assessing the suitability of the raw clays to make CEB. These analyses allow for classifying the sampled clay deposits in three categories: clays that can be used unchanged to make CEB (2 clay deposits), clays that are suitable for the manufacture of CEB but require addition of sand and gravel particles (13 clay deposits) and clays that are suitable for the manufacture of CEB if they are mixed with other raw clays (4 clay deposits). In order to verify the use of these clays, five of them served as a model for making CEB. The strength of these bricks was evaluated by testing for compressive strength and abrasion resistance. The results of these tests confirm the suitability or not of the sampled clays for the manufacture of CEB.
\end{abstract}

KEYWORDS: Clay deposit, raw earth, compressive strength, abrasion resistance.

\section{Introduction}

Faced with the current environmental challenges about climate change and depletion of earth's resources (UNEP/UNECE, 2016), the building sector needs to renovate its design practices and methods by taking into account economic, sanitary and comfort criteria. The development of materials that address these criteria and promotion of their use is put forward. Raw earth is one of these materials (Niroumand et al., 2017).

Raw earth designates the earth used in construction unfired but simply dried. Earth construction techniques are very varied: adobe (the molded and sun dried brick), cob (construction made by stacking earth balls handmade), wattle and daub (the earth used in filling load-bearing structures, usually made of wood), rammed earth (earth compacted in a framework), and Compressed Earth Block (compacted earth, achieved using manual or mechanical presses) are the main ones (CRAterre et al. 1979; Houben \& Guillaud, 1989). Raw earths can be used to produce compressed earth blocks (CEB) with ecological, thermal and economic advantages. However, the raw earth blocks have the disadvantage of deteriorating to humidity change or abrasion. This decreases its durability, i.e. resistance over time (Rigassi, 1995). Stabilization is a process to improve the impermeability (water resistance) and the hardness (impact and friction resistance, reduction of crumbling) of the earth block. There are more than a hundred products stabilizing the earth: sand, gravel, cement, lime, bitumen, resins, fibers, ... (Houben \& Guillaud, 1989). Stabilization is not necessary when the material is not exposed to water (coated walls, interior walls, protected walls) but becomes indispensable in the opposite case (Houben \& Guillaud, 1989).

The use of raw earth for construction purposes remains widespread in many rural parts of the world. In Europe, its use is generally considered incompatible with modern constructions standards. What followed is a loss of expertise (Projet Terra Incognita, 2014).

Currently, raw earth is reconsidered because of its particular benefits: it is an ecological, economical and healthy material providing thermal, hygrothermal and acoustic comfort to the building (Houben \& Guillaud, 1989; Fontaine \& Anger, 2009; Trachte, 2012; Echarri \& Brebbia, 2016).

In Belgium, the remaining examples of earthen architecture are rare and the potential for this architecture remains unknown to the public. After industrialization in the early 19th century, Belgium has experienced a rapid increase of materials from industrial production (concrete, fired bricks, and metal). This profoundly changed the monumental heritage (Bronchart \& Bavay, 2011). The new interest for raw earth construction resumed in 1990 in Belgium, when several professionals, composed of builders and architects, formed an association named TerraMorpho, and introduced the clay-straw construction technique in Belgium
(Bronchart \& Bavay, 2011). Currently, the raw earth industry in Belgium concerns three families of complementary building materials: raw earth bricks, coatings and other bulk products (e.g. ramming mixes). Two types of earth bricks are currently marketed in Belgium: natural bricks without additions, intended for indoor use, for non-load bearing walls, and bricks with sand or lime additions for outdoor use and load-bearing walls. Following the renewed interest in these products, local producers (e.g. Argio, Argibat, Lebailly) are emerging. Their offer is supplemented by companies that prepare coatings and other bulk materials (e.g. Hins, Le Comptoir des Argiles, Morpha Minera). These companies offer local alternatives to the importation of foreign products, mainly those of Claytec (Germany), Argilus (France) and Tierrafino (Netherlands) (LOCI, 2016).

In several regions of Belgium, there are important clay deposits, used in ceramic industry. The main clay deposits exploited in Belgium are polder clays, Boom Formation clay, Campine clays, Ieper Group clays, Hainaut Group clays, loam and alluvial silt and weathered shale (Gulinck, 1958; Laga et al. 2001). These clays are the raw material used for this study.

Not all natural earths are suitable for CEB construction technique. The earth use standards in $\mathrm{CEB}$ construction vary from one country to another and are often based on granulometry, cohesion, chemical and/or mineralogical composition, characteristics on which the behavior of final products depends (Jiménez \& Guerrero, 2007; Sitton et al., 2017). These are nonrestrictive norms because earth that does not comply with these norms nevertheless can give good CEB when it is modified (Riza et al., 2010; Moevus et al., 2012). Currently, in Belgium there are no standards for earth bricks, but the many clay-bearing sedimentary deposits suggest that there is a clear potential for development. This study is motivated by the need for basic knowledge about the CEB potential.

The objective of this research is the characterization of a wide range of Belgian clay deposits for their ability for the manufacture of raw earth bricks, according to the technique of compressed earth blocks. Thereafter, some clay samples of different nature are effectively tested for making CEB.

\section{Sampling}

Fieldwork consisted of prospecting and sampling clay deposits in Belgium. Exploration, outcrop description and mapping of the deposits were achieved using classical prospecting surveys (manual auger borings, sampling on the quarry fronts). A total of 56 sites were sampled (Fig. 1), and 135 samples were collected. Each sample contained about $3 \mathrm{~kg}$ of material. The geographic coordinates of the sites are presented in Appendix 1, stratigraphy according to National Commission for Stratigraphy Belgium (NCS, 2019) and/or to Boulvain \& Pingot (2015). 


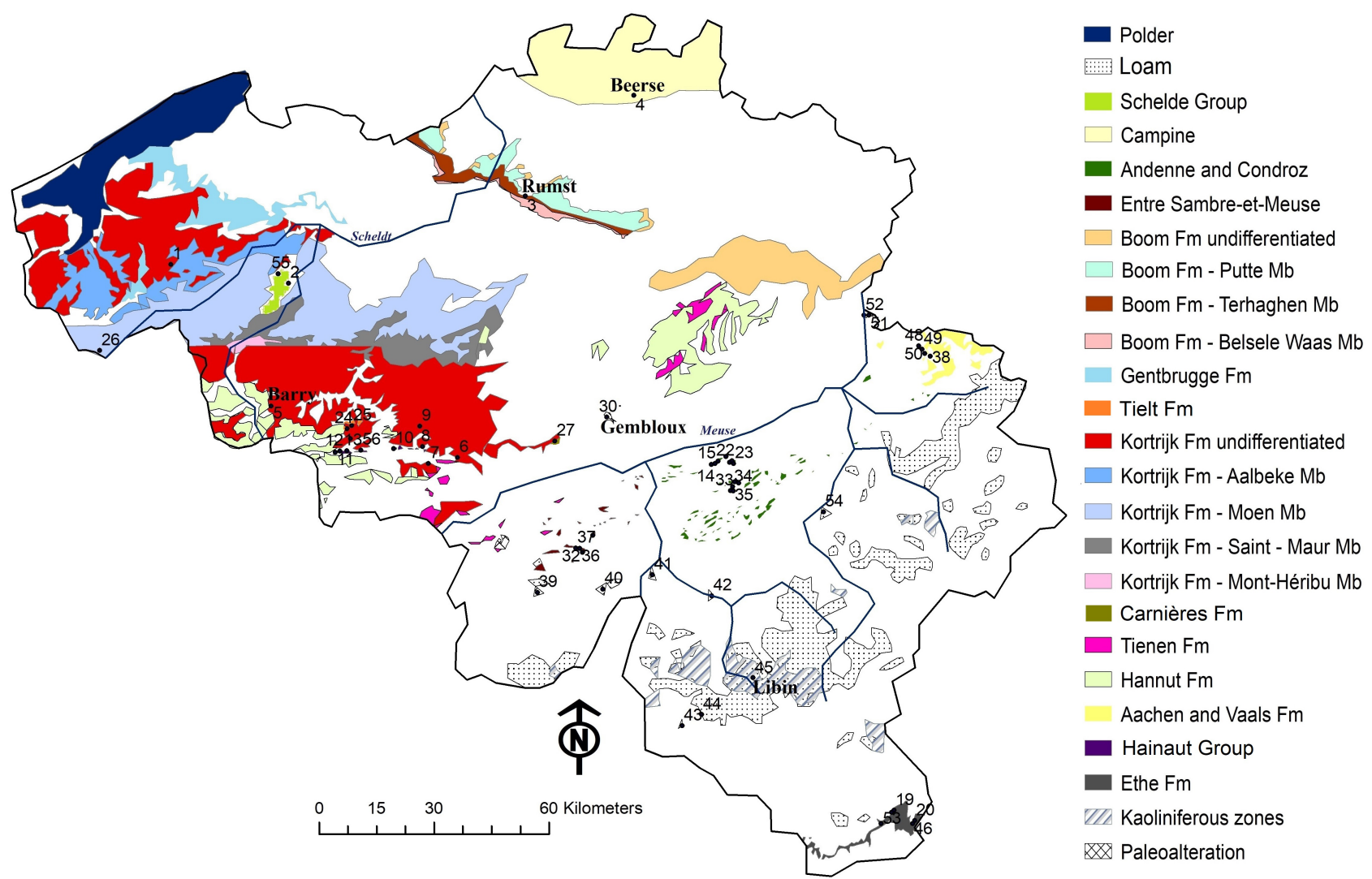

Figure 1. Location of sampled sites on the map of Belgian clay deposits. The numbers correspond to the sampled sites (modified from DOV, 2001; Rekk, 2014; Haesaerts et al., 2016).

Sampled clay deposits are detailed hereafter.

1) Schelde Group clays: the alluvial plains of the Scheldt river basin contain sediments with a fine sandy-silty texture, assigned to the Middle Pleistocene Eeklo and Late Pleistocene Arenberg Formations (NCS, 2019) interstratified with other sediments such as clay, sand to gravel, peat and/or calcareous tufa (Gullentops et al., 2001).

2) Loam deposits: Middle Belgium and parts of Upper Belgium are covered by a continuous mantle of aeolian loess, largely weathered into loam (Calembert, 1947; Gulinck, 1958). These are assigned to the early Pleistocene Veldwezelt and late Pleistocene Gembloux Formations (Haesaerts et al., 2011; NCS, 2019).

3) Campine clays: these are estuarine deposits of Belgian rivers during the early Quaternary (early Pleistocene). These consist of clays and fine sands assigned to the Rijkevorsel and Turnhout Members of the Weelde Formation of Lower Pleistocene age (Bogemans, 1997).

4) Clays of Andenne and Condroz: these plastic clays of late Oligocene age are localized in the paleokarsts formed in the carbonates of Givetian, Frasnian, Tournaisian and Visean from the region between Andenne and Dave (Calembert, 1945; Dupuis et al., 1996; Nicaise \& Dupuis, 1997). The dissolution pockets, up to 100 meters deep, evolved into karst lakes that were clogged by the alteration products of the surrounding shale rocks. These deposits are very irregular, and composed of sands, clays and lignites (Nicaise \& Dupuis, 1997; Goemaere \& Declercq, 2010; Goemaere \& Quinif, 2010).

5) Clays of Entre-Sambre-et-Meuse: these occupy dissolution pockets located in the limestone bands of Lower Carboniferous or Devonian age of the Dinant Synclinorium (Gulinck, 1958). They were formed at the same time and according to the same mechanisms as the clays of Andenne and Condroz (Gulinck, 1958).

6) Boom Formation clay: corresponding to marine fine detrital deposits of Rupelian age (Lower Oligocene). The Boom clay consists of a cyclic alternation of (clayey) silt and clay layers (Wouters \& Vandenberghe, 1994; Vandenberghe et al., 1997; De Craen et al., 1999). The lithostratigraphic subdivision of the Boom
Formation consists of three members: the Belsele-Waas Member is characterized by coarser granulometry, silt-enriched layers on top and thicker layers, the Terhagen Member is less silty, and the Putte Member is characterized by silty clay layers enriched in organic matter (Vandenberghe et al., 1997; Vandenberghe et al. 2014; Vandenberghe, 2017).

7) Ieper Group clays: they were deposited during the Lower Eocene transgression that flooded Flanders, Hainaut and Brabant. They are mainly marine and consist of fine sand, silty clays and plastic clays. The most clayey part of the Ieper Group is composed of the Kortrijk and Tielt Formations. The Carnières Formation is a lateral equivalent of the Orchies and Roubaix Members of the Kortrijk Formation (Maréchal, 1993; Steurbaut, 1998; Maréchal \& Laga, 1988; Laga et al., 2001; Steurbaut et al., 2016; Steurbaut \& King, 2017).

8) Landen Group clays: these deposits are related to the Thanetian transgression (Late Paleocene) and consist of sand, tuffaceous sandstone, sandy clay and heavy clay (Doremus \& Hennebert, 1995; De Geyter, 1981). They are subcropping in southern Brabant and Hainaut (Tavernier \& Gulinck, 1947) as the Formations of Hannut and Tienen.

9) Vaals Formation clay: it constitutes a marine deposit accumulated in the Herve region during the Cretaceous transgression of the Cenomanian to the Maastrichtian, more particularly during the lower Campanian (Marlière, 1954; Robaszynski et al., 2001). It is also known as "Herve Smectite" (Marlière, 1954).

10) Aachen Formation clay: the Aachen Formation is a fluvio-estuarine deposit accumulated in the region of Herve during the Cretaceous transgression from the Cenomanian to the Maastrichtian. Near the type locality, the Aachen Formation attains $100 \mathrm{~m}$ in thickness (Laloux et al., 1996). This formation consists of yellow and white sand with clay levels of 5 to 15 meters thick (Barchy \& Marion, 2000).

11) Hainaut Group clays (Wealdian facies clays): they form the lower part of a sedimentary sequence accumulated in the Mons Basin (Marlière, 1954). They probably result from alteration of the Brabant Massif and the upper Carboniferous shales of northern Hainaut during the early Cretaceous marine 
transgressions (Albian to Cenomanian) (Yans et al., 2002). They crop out along the northern rim of the Mons Basin over 40 kilometers between Hautrage and Thieu (Yans et al., 2002; Spagna et al. 2008). Wealdian deposits are also trapped in karst pockets of Dinantian limestones to the north of the Wealden Clay outcrop zone (Legrand, 1968; Vergari \& Quinif, 1997).

12) Ethe Formation clay: this formation is located in a set of sedimentary deposits that result from successive periods of transgression and regression from east to west that have marked the Jurassic of Belgian Lorraine (Maubeuge, 1954). It consists of claystones, micaceous silty argillites and carbonate clay (marl) (Boulvain et al., 2000).

13) Paleoalteration clays: these are mainly clays from the in situ alteration of shales and schists. Besides the continental clays of Andenne and Condroz, and the Sambre-et-Meuse trapped in paleokarsts resulting from the dissolution of a carbonate substrate, there are other kaolinitic clays forming the weathering products of Devonian or Ordovician to Cambrian shaly sandstone, shale and schist generated during continental weathering and peneplanation of the Ardenne at different stages, from Mesozoic to Neogene. These can be covered with aeolian silt-loam or mixed with them (Spagna et al., 2006). Kaolins correspond to a primary type deposit or residual kaolin from the weathering of shales and arkoses. They are present on the Rocroi Massif across the border in France (Voisin, 1995) and on the peneplanated ridges of the High Ardenne (Dupuis et al., 1996, Demoulin et al, 2018).

\section{Raw clays characterization}

The laboratory analyzes covered the characterization of the raw clay materials selected during prospecting with the following properties: particle size, plasticity, nature and mineralogy.

\subsection{Particle size}

Granulometric analysis classifies the grains of a sample according to their size and gives the percentage of each class relative to the total weight of the sample. The particle size distribution has an important role in shaping and drying.

The particle size of the samples was carried out by both sieving and wet laser granulometry. The laser granulometry allows for classifying the particles whose diameter is between $900 \mu \mathrm{m}$ and $0.05 \mu \mathrm{m}$. The sieving permits the classification of particles beyond $900 \mu \mathrm{m}$. The laser granulometry was carried out in the Structural Chemistry Laboratory of University of Liège, using the particle size analyzer Malvern Mastersizer 2000. The sieving was carried out in the Geotechnologies Laboratory of University of Liège.

According to Rigassi (1995), soil recommended for the manufacture of CEB without stabilizer contains 0 to $40 \%$ gravel, 25 to $80 \%$ sand, 10 to $25 \%$ silt and 8 to $30 \%$ clay. However, many soils that do not correspond to the recommended grain size distribution may yield good results, depending on the stabilizers used (Houben \& Guillaud, 1989; Rigassi, 1995). Granulometry is therefore not a restrictive selection criterion.

\subsection{Plasticity}

The plasticity or Atterberg limits is used to classify soils, and to predict their behavior when they are mechanically loaded. They correspond to the proportions in water for which the soil material passes from a semi-liquid behavior to a plastic behavior (liquid limit $\mathrm{W}_{\mathrm{L}}$ ), and then from a plastic behavior to a semi-solid behavior (plastic limit $\mathrm{W}_{\mathrm{p}}$ ) (Peltier \& Rumpler, 1959). The Atterberg limits are realized on a material whose particle size is $<425 \mu \mathrm{m}$ using the Casagrande cup for the Liquid limit measurement. The Atterberg limits were carried out in the Geotechnologies Laboratory of University of Liège.

The Atterberg limits are used to calculate the plasticity index (PI). It is obtained by the difference between the liquid limit and plastic limit: $\mathrm{PI}=\mathrm{W}_{\mathrm{L}}-\mathrm{W}_{\mathrm{P}}$. It characterizes the interval where the soil material remains plastic or shapeable.

For the manufacture of CEB, a plasticity index close to 9 is recommended, or between 7 and 25; a liquid limit close to 27 or between 25 and 45; and a plastic limit close to 17 or between 10 and 25 (Guérin, 1985; Houben \& Guillaud, 1989; Rigassi, 1995; AFNOR, 2001; Jiménes \& Guerrero, 2007).

\subsection{Nature}

The nature of soil is determined by the combination of the values from the particle size, plasticity and methylene blue values (Fig. 2). The value of methylene blue (VBS in $\mathrm{g}$ of blue $/ \mathrm{kg}$ of clay material) is used to determine the clay fraction. It is obtained by the methylene blue test. This test is done by adding a solution of methylene blue in a clay material suspension placed in distilled water. A drop of the suspension is taken periodically and deposited on a chromatographic paper. The quantity of clay fraction present in the sample is evaluated by the form of the drop taken (AFNOR, 2013). The methylene blue tests were carried out in the Geotechnologies Laboratory of the University of Liège.

\subsection{Mineralogy}

The mineralogical analysis was done by X-ray diffraction, on bulk powder and clay fraction (less than $2 \mu \mathrm{m}$ ). The analysis was carried out in the Argiles, Géochimie et Environnements sédimentaires Laboratory of University of Liège, using Bruker D8 Advance X-ray diffractometer. The semi-quantitative interpretation of the diffractograms was based on the height of the peaks.

\section{Classification of sampled raw clays}

Appendix 1 summarizes the properties of the raw clays sampled.

The results allow to classify the studied raw clays in three categories: raw clays that can be used unchanged to make CEB (first category), raw clays that are suitable for the manufacture of CEB but require modification by addition of coarse particles like sand or gravel (second category) and raw clays that are suitable to the manufacture of CEB if they are mixed with other raw clays to give them a better consistency and possibly coarse particles (sand, gravel) (third category) (Table 1).

\section{CEB characterization}

\subsection{Realization of $C E B$}

Five clay formations were chosen to produce CEB. These five clays served as a guide to evaluate the suitability of all the clays sampled for the manufacture of CEB. They were chosen on the basis of their diversity.

1) The Campine clay (Turnhout Member) in Beerse: this is a deposit rich in sand (53\%), containing $6 \%$ clay and $41 \%$ silt. It is moderately plastic. Its clay mineralogy is characterized by smectite associated with illite. The Turnhout Member in Beerse was classified as suitable for CEB manufacture.

2) The Boom Formation clay (Putte Member) in Rumst: its clay mineralogy is dominated by illite associated with kaolinite. It has a high silt content (72\%) and little fine sand (16\%). The Putte Member clay in Rumst was classified as acceptable, but requiring modification by adding coarse particles (sand, gravel).

3) The Ieper Group clays (Kortrijk Formation - Orchies Member) in Tournai: it is moderately plastic clay (plasticity index between 5 and 15). It is characterized by clay mineralogy dominated by illite and smectite, and fine particle size distribution (clay $<11 \%$, silt 80 to $90 \%$, sand 5 to $10 \%$ ). The Orchies Member clay in Tournai was classified as acceptable, but requiring modification by adding coarse particles (sand, gravel).

4) The clay related to the paleoalterations of Ordovician shales in Gembloux: it is a raw clay rich in illite, without smectite, and not plastic (plasticity index $<5$ ). It is also characterized by a fine grain size distribution ( $9 \%$ clay, $85 \%$ silt and $6 \%$ fine sand). The clay related to the paleoalteration of Ordovician shales in Gembloux was classified as not suitable for CEB manufacture if not mixed with other materials (clays, sand, gravel).

5) The alteration clay of Devonian shales at Libin: it is a nonplastic clay, with less than $7 \%$ clay, 48 to $87 \%$ silt and 2 to $48 \%$ sand. Its clay mineralogy is dominated by kaolinite. The clay related to the alteration of Devonian shales at Libin was classified as not suitable for CEB manufacture if not mixed with other materials (clays, sand, gravel).

These samples were dried at $40{ }^{\circ} \mathrm{C}$ in a dryer. They were then milled using a grinder to break up the concretions of clay. 


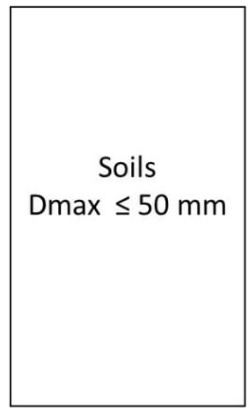

Passing at $80 \mu \mathrm{m}$

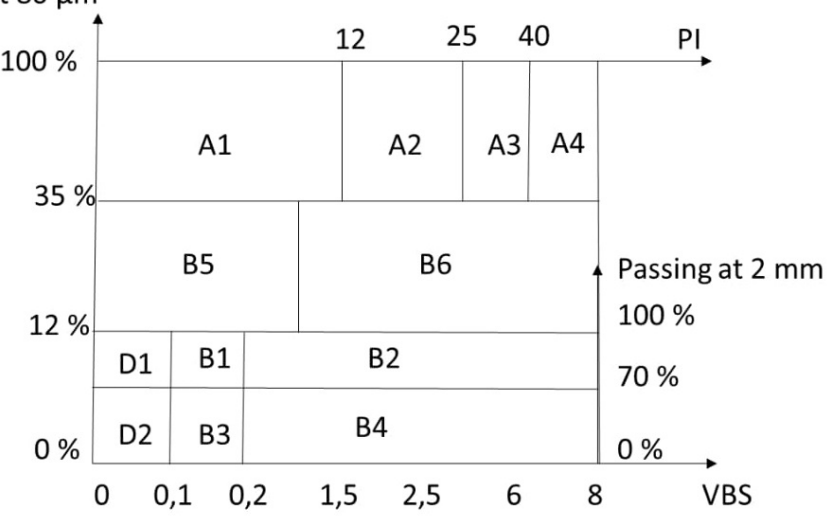

Passing at $80 \mu \mathrm{m}$
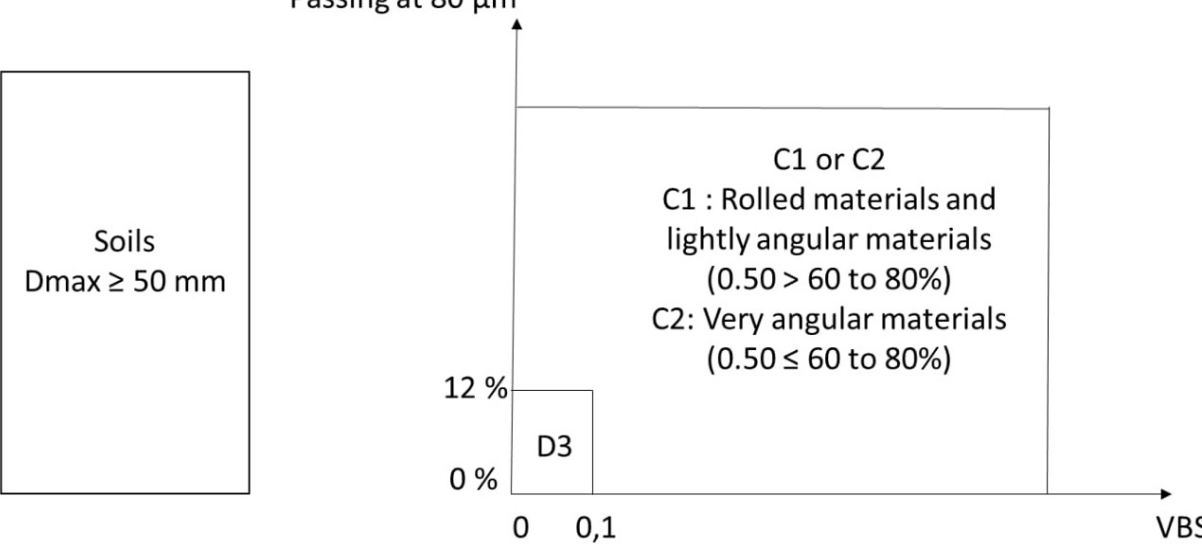

Figure 2. Soil classification by nature. A1: acceptable material but having a bit too much fines. A2: acceptable material but having too many fines. A3: acceptable material but requiring special attention because relatively active. A4: delicate material to use because very active. B1: sandy material requiring an addition of fines to be acceptable. B2: acceptable material having a slight deficit of fines. B3: sandy material requiring a considerable addition of fines to be acceptable. B4: acceptable material having a deficit of fines. B5: acceptable material but lacking a few fines. B6: acceptable material but missing some fines. $\mathrm{C} 1$ : too gritty material, must be screened to change its nature. $\mathrm{C} 2$ : too gritty material, must be screened to change its nature. D1: sandy material requiring an addition of fines to be acceptable. D2: sandy material requiring a considerable addition of fines to be acceptable. D3: gravelly material requiring a screening to change its nature and a considerable addition of fines to be acceptable. R: unsuitable materials (rocky materials). F: materials that require extensive identification tests, particularly with regard to their chemical analysis and mechanical tests before being able to determine their suitability (AFNOR, 2001).

$\mathrm{R}:$ Rocky materials (Sedimentary rocks, magmatic and metamorphic rocks)

F : Special materials (organic soils and industrial by-products)

Table 1. Classification of raw clay formations.

\begin{tabular}{|c|c|c|}
\hline Categories & Sampled raw clays & Description \\
\hline $1^{\text {st }}$ & $\begin{array}{l}\text { - Campine clays (Weelde Formation, Turnhout Member) } \\
\text { - Paleoalteration clays of Famennian shales }\end{array}$ & $\begin{array}{l}\text { Acceptable material, good particle size } \\
\text { distribution and good consistency. } \\
\text { They can be used unchanged to make } \\
\text { CEB. }\end{array}$ \\
\hline $2^{\text {nd }}$ & $\begin{array}{l}\text { - Schelde Group clays } \\
\text { - Campine clays (Weelde Formation, Rijkevorsel Member) } \\
\text { - Clays of Andenne and Condroz } \\
\text { - Clays of Entre Sambre-et-Meuse } \\
\text { - Boom Formation clay (Putte Member) } \\
\text { - Ieper Group clays (Tielt Formation; Kortrijk Formation; } \\
\quad \text { Carnières Formation) } \\
\text { - Landen Group clays (Hannut Formation) } \\
\text { - Vaals Formation clay } \\
\text { - Aachen Formation clay } \\
\text { - Hainaut Group clays } \\
\text { - Ethe Formation clay }\end{array}$ & $\begin{array}{l}\text { Acceptable material but containing too } \\
\text { much fine particles and requiring an } \\
\text { addition of coarse particles (sand, } \\
\text { gravel) to make CEB. }\end{array}$ \\
\hline $3^{\text {rd }}$ & $\begin{array}{l}\text { - Loam } \\
\text { - Paleoalteration clays of Devonian shales } \\
\text { - Paleoalteration clays of Ordovician shales } \\
\text { - Ardennes kaolin }\end{array}$ & $\begin{array}{l}\text { Raw clays with low consistency. They } \\
\text { need to be mixed with other materials } \\
\text { (clays, sands, gravel) to be used to } \\
\text { produce CEB. }\end{array}$ \\
\hline
\end{tabular}


Once the preparation of the sample is complete, a volume dosage of the sample is made for mixing with the water. For each mixture, the amount of water added is $12 \%$ of the total mass of the soil fraction in the mixture. After mixing, the CEB were made by pressing, using a hand press. Three blocks were made for each type of raw clay. After demolding the blocks are dried at $40{ }^{\circ} \mathrm{C}$. A complete drying is reached when the mass measured between two successive days does not change any more. The manufactured CEB are $29.5 \times 14 \times 9.5 \mathrm{~cm}(\mathrm{~L} \times \mathrm{W} \times \mathrm{H})$. All of these tests and the measurements of compressive strengths and abrasion resistance were carried out in the Laboratory of Building Materials of the University of Liège.

\subsection{Compressive strength and abrasion resistance}

Compressive strength is the main mechanical property of the earth brick that interests the builders (Houben \& Guillaud, 1989). It is the only mechanical property that is subject to strong regulatory requirements. The higher the compressive strength is, the lower the thickness of the walls can be (Jiménez \& Guerrero, 2007).

There are several operating procedures for determining compressive strength. The compressive strength of the CEB is either measured on a masonry unit (block and joint), on a half block, or a whole block (individual unit) (Morel et al., 2007). In this study, the compressive strength was measured according to the method developed by Walker (2000), on a whole block. Two iron plates were placed on both surfaces of the block before the application of the load, as shown in Figure 3. The block is then loaded at constant rate $(144 \mathrm{kN} / \mathrm{min})$ until rupture.

The abrasion resistance is evaluated by the weight loss of a sample subjected to abrasion simulated by the brush test. It consists of brushing the surface of the block with a wire brush, one round trip per second for one minute without applying vertical force on the brush. At the end of the brushing process, the block is cleaned of elements that have come loose and then weighed again (AFNOR, 2001).

The coefficient of abrasion $\mathrm{Ca}\left(\mathrm{in} \mathrm{cm}^{2} / \mathrm{g}\right.$ ) is conventionally expressed by the formula:

$$
\mathrm{Ca}=\frac{\mathrm{S}}{\mathrm{m} 0-\mathrm{m} 1}
$$

$\mathrm{S}$ : brushed surface (length $\mathrm{x}$ width brushed);

m0: mass of the block before brushing;

$\mathrm{m} 1$ : mass of the block after brushing.

Abrasion resistance only applies to blocks intended to be exposed to the risk of abrasion resulting from human activity (AFNOR, 2001).

The values of the compressive strengths and abrasion resistance are presented in Table 2.

Depending on the standard used and the country of reference, the minimal compressive strength required for CEB differs, ranging from 1.3 to $3.5 \mathrm{MPa}$ (Fig. 4).

The compression test confirms that clays related to paleoalterations of Ordovician shales in Gembloux and the Ardennes kaolins are not suitable for making CEB if not mixed with other materials (clay, sand, gravel). Their compressive strengths are low $(0.24$ and $0.12 \mathrm{MPa})$, below all standards. The Boom (Putte Member) and Ieper Group (Orchies Member) clays are acceptable for the manufacture of the CEB. They

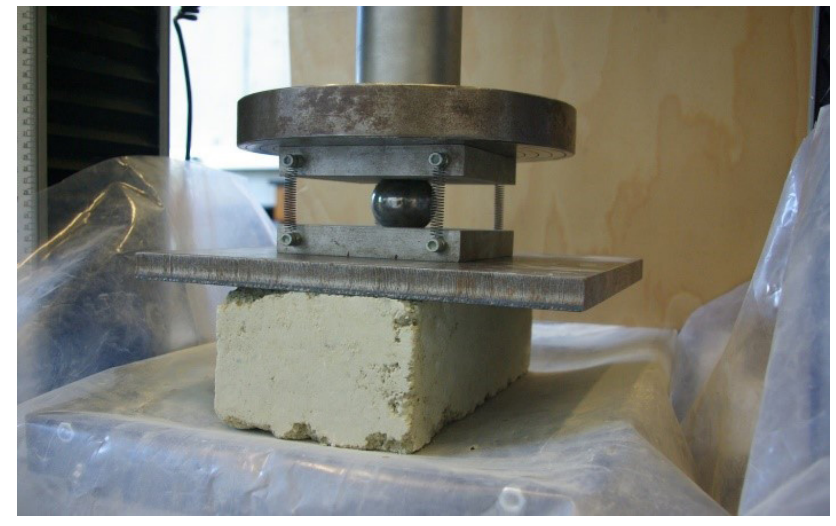

Figure 3. Testing for compressive strength.

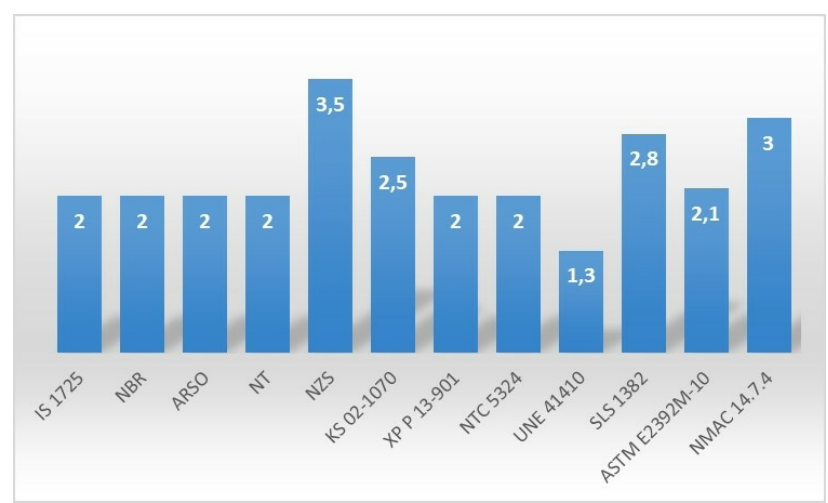

Figure 4. $\mathrm{CEB}$ minimum values of dry compressive strength (MPa) according to different standards: IS 1725 (India), NBR (Brazil), ARSO (Africa), NT (Tunisia), NZS (New Zealand), KS 02-1070 (Kenya), XP P13- 901 (France), NTC 5324 (Colombia), UNE 41410 (Spain), SLS 1382 (Sri Lanka), ASTM E2392M-10 (America), NMAC 14-7-4 (New Mexico), (after Jaime et al., 2012).

have compressive strengths between the minimum values of the different standards (3.06 and 2.16 MPa). Nevertheless they have to be used with care. The Campine clay (Turnhout Member) is perfectly suited to the manufacture of $\mathrm{CEB}$, with a compressive strength $(5.13 \mathrm{MPa})$ above the minimum values of the different standards.

The abrasion resistance $\mathrm{Ca}$ coefficient of the blocks intended for external walls must be at least equal to $5 \mathrm{~cm}^{2} / \mathrm{g}$ (AFNOR, 2001).

On the basis of the results of the abrasion resistance test, we can conclude that the clays related to the paleoalterations of the Ordovician shales in Gembloux and the Ardennes kaolin are not adapted to the construction of the CEB if not mixed with other materials (clay, sand, gravel). Their resistance to abrasion is low $\left(0.7\right.$ and $\left.0.5 \mathrm{~cm}^{2} / \mathrm{g}\right)$, below the recommended value. The Boom (Putte Member) and Ieper Group (Orchies Member) clays have

Table 2. Values of compressive strengths and abrasion resistance of the five samples selected for producing CEB.

\begin{tabular}{lcc}
\hline Raw clays & $\begin{array}{c}\text { Compressive strength } \\
(\mathrm{MPa})\end{array}$ & $\begin{array}{c}\text { Abrasion resistance } \\
\left(\mathrm{cm}^{2} / \mathrm{g}\right)\end{array}$ \\
\hline The Turnhout Member clay & 5.13 & 7.3 \\
The Putte Member clay & 3.06 & 4.1 \\
The Orchies Member clay & 2.16 & 3.6 \\
Paleoalteration clay of Ordovician shales in Gembloux & 0.24 & 0.7 \\
Ardennes kaolin & 0.12 & 0.5 \\
\hline
\end{tabular}


an abrasion resistance lower than the recommended value (4.1 and $\left.3.6 \mathrm{~cm}^{2} / \mathrm{g}\right)$. They have to be used with care. The Campine clay (Turnhout Member) is perfectly suited to the manufacture of CEB, with an abrasion resistance $\left(7.3 \mathrm{~cm}^{2} / \mathrm{g}\right)$ above the recommended value.

\section{Conclusion}

In several regions of Belgium, there are important clay formations, used for the manufacture of bricks, tiles, pottery, and also in the cement industry. Altogether 19 clay deposits have been characterized on the basis of particle size, plasticity, nature and mineralogy in order to evaluate their use for manufacture of compressed earth blocks (CEB). The raw clays were classified in three categories according to their aptness to make CEB: 4 of them (loam deposits, paleoalteration clays of Devonian shales, paleoalteration clays of Ordovician shales and Ardennes kaolin) are not suitable for making CEB without being mixed with other materials (clays, sand, gravel), 13 of them (Schelde Group clays, Rijkevorsel Member of Weelde Formation, clays of Andenne and Condroz, clays of Entre Sambre-et-Meuse, Putte Member, Tielt Formation, Kortrijk Formation, Carnières Formation, Hannut Formation, Vaals Formation clay, Aachen Formation clay, Hainaut Group clays, Ethe Formation clay) are acceptable for making CEB but require modification by adding coarse particles (sand, gravel); and 2 of them (Turnhout Member of Weelde Formation, paleoalteration clays of Famennian shales) can be used without modification. Moreover, five samples were selected on the basis of their diversity to make CEB and were subsequently characterized by compression and abrasion resistance tests. Two samples out of the five chosen were classified as not suitable for the manufacture of CEB if they are not mixed with other materials (clay, sand, gravel). These showed very low compression and abrasion resistance values. Two samples out of the five chosen were classified as acceptable for the manufacture of CEB with addition of coarse particles. These have acceptable compression and abrasion resistance. The sample out of the five chosen which was classified as suitable for the manufacture of CEB shows very high compressive and abrasion resistance.

\section{Acknowledgements}

The authors thank Michaël Maertens, Laure Vandemeulebroeke, Hilde Chambart, Georges Borremans, Yolande Jorissen, Arnaud Hins, Francis Deboever, Deroose Marleen, Philippe Delporte, Kevin Meessen, Lambert Mayers, Solange Hermans-Charlier, Brecht Embo, Frederic Duquennois, Pierre Flament, Jean-Benoît Collee and Alain Nicolas who helped in the collection of samples by giving access to their clay pits. The authors also thank the reviewers, Kris Welkenhuysen and Michiel Dusar who helped to improve the quality of this paper.

\section{References}

AFNOR, 2001. XP P13-901. Compressed earth blocks for walls and partitions: definitions - specifications - test methods - delivery acceptance conditions. La Plaine Saint-Denis, AFNOR Éditions, $35 \mathrm{p}$.

AFNOR, 2013. NF EN 933-9. Essais pour déterminer les caractéristiques géométriques des granulats - Partie 9 : qualification des fines - essai au bleu de méthylène. La Plaine Saint-Denis, AFNOR Éditions, 21 p.

Barchy, L. \& Marion, J.-M., 2000. Carte géologique de Wallonie : Dalhem - Herve 42/3-4. 1/25 000. Namur, Ministère de la Région wallonne, Direction générale des ressources naturelles et de l'environnement, avec une notice explicative de $71 \mathrm{p}$.

Bogemans, F., 1997. Toelichting bij de Quartairgeologische kaart. Kaartblad 1 - 7, Essen - Kapellen. Vlaamse Overheid, Dienst Natuurlijke Rijkdommen, Brussel, 39 p.

Boulvain, F. \& Pingot, J-L., 2015. Genèse du sous-sol de la Wallonie. $2^{\text {nd }}$ ed. Académie royale de Belgique, Mémoire de la Classe des Sciences, coll. In- $8^{\circ}, \mathrm{IV}^{\circ}$ série, tome V, $208 \mathrm{p}$.

Boulvain, F., Belanger, I., Delsate, D., Dosquet, D., Ghysel, P., Godefroit, P., Laloux, M., Roche, M., Teerlynck, H. \& Thorez, J., 2000. New lithostratigraphical, sedimentological, mineralogical and palaeontological data on the Mesozoic of Belgian Lorraine: a progress report. Geologica Belgica, 3, 3-33.
Bronchart, S. \& Bavay, G., 2011. Earthen architecture in Belgium. In Correia, M., Dipasquale, L., Mecca, S. \& Akermann, K. (eds), Terra Europae: Earthen architecture in the European Union. Edizioni ETS, Pisa, 90-94.

Calembert, L., 1945. Les gisements de terre plastiques et réfractaires d'Andenne et du Condroz. Vaillant-Carmanne, Liège, 240 p.

Calembert, L., 1947. Phosphates de la Hesbaye. Étages Sénonien et Maestrichtien. In Centenaire de l'Association des Ingénieurs sortis de l'Ecole de Liège, Congrès 1947, Section géologie, 341-344.

CRAterre [Centre de recherche et d'application pour la construction en terre], Doat, P., Hays, A., Houben, H., Matuk, S. \& Vitoux, F., 1979. Construire en terre. Alternatives et Parallèles, Paris, Anarchitecture, 265 p.

Databank Ondergrond Vlaanderen (DOV), 2001. Tertiair geologische kaart 1/50.000. Belgische Geologische Dienst en Vlaamse overheid, afdeling Land en Bodembescherming, Ondergrond, Natuurlijke Rijkdommen. https://www.dov.vlaanderen.be, accessed 04/22/2019.

De Craen, M., Swennen, R. \& Keppens, E., 1999. Petrography and geochemistry of septarian carbonate concretions from the Boom Clay Formation (Oligocene, Belgium). Geologie en Mijnbouw, 77, 63-76. https://doi.org/10.1023/A:1003468328212

De Geyter, G., 1981. Contribution to the lithostratigraphy and sedimentary petrology of the Landen Formation in Belgium. Mededelingen van de Koninklijke Academie voor Wetenschappen, Letteren en Schone Kunsten van België, Klasse Wetenschappen, 43, 111-153.

Demoulin, A., Barbier, F., Dekoninck, A., Verhaert, M., Ruffet, G., Dupuis, C. \& Yans, J., 2018. Erosion surfaces in the Ardenne-Oesling and their associated kaolinic weathering mantle. In Demoulin, A. (ed.), Landscapes and Landforms of Belgium and Luxembourg. Springer, Cham, World Geomorphological Landscapes, 63-84. https://doi.org/10.1007/978-3-31958239-9 5

Doremus, P. \& Hennebert, M., 1995. Carte géologique de Wallonie : Lens - Soignies 39/7-8. 1/25 000. Namur, Ministère de la Région wallonne, Direction générale des ressources naturelles et de l'environnement, avec une notice explicative de $54 \mathrm{p}$.

Dupuis, C., Charlet, J-M., Dejonghe, L. \& Thorez, J., 1996. Reconnaissance par carottage des paléoaltérations kaolinisées mésozoïques de la Haute Ardenne (Belgique). Le sondage de Transinne (194E-495): premiers résultats. Annales de la Société géologique de Belgique, 119, 91-109.

Echarri, V. \& Brebbia, C. A., 2016. Eco-Architecture VI: Harmonisation between Architecture and Nature. Wessex Institute of Technology Press, Southampton, $292 \mathrm{p}$.

Fontaine, L. \& Anger, R., 2009. Bâtir en terre : Du grain de sable à l'architecture. Belin, Paris, 224 p.

Goemaere, E. \& Declercq, P.-Y., 2010. Les gisements de terres plastiques d'Andenne. In Goemaere, E., (éd.), Terres, Pierres et Feu en Vallée mosane. Service géologique de Belgique, Bruxelles, Collection Geosciences, 399-408.

Goemaere, E. \& Quinif, Y., 2010. La géologie des terres plastiques d'Andenne. In Goemaere, E., (éd.), Terres, Pierres et Feu en Vallée mosane. Service géologique de Belgique, Bruxelles, Collection Geosciences, 373-385.

Guérin, L., 1985. Principes directeurs pour l'emploi de la terre crue : Construction à faible coût dans les programmes spéciaux de travaux publics. Bureau international du travail, Genève, $219 \mathrm{p}$.

Gulinck, M., 1958. Carrières : Atlas de Belgique, Planche 39. Académie Royale de Belgique, Comité national de Géographie, Commission de l'Atlas National, Bruxelles, 27 p.

Gullentops, F., Bogemans, F., De Moor, G., Paulissen, E. \& Pissart, A., 2001. Quaternary lithostratigraphic units (Belgium). In Bultynck, P. \& Dejonghe, L. (eds), Guide to a revised lithostratigraphic scale of Belgium. Geologica Belgica, 4/1-2, 153-164.

Haesaerts, P., Pirson, S. \& Meijs, E., 2011. Gembloux Formation. National Commission for Stratigraphy Belgium. https://ncs.naturalsciences. be/quaternary/412-gembloux-formation, accessed 04/22/2019

Haesaerts, P., Damblon, F., Gerasimenko, N., Spagna, P. \& Pirson, S., 2016. The Late Pleistocene loess-palaeosol sequence of Middle Belgium. Quaternary International, 411, A, 25-43. https://doi. org/10.1016/j.quaint.2016.02.012

Houben, H. \& Guillaud, H., 1989. Traité de construction en terre. Marseille, Parenthèses, $355 \mathrm{p}$.

Jaime C-F., Mazarrón F. R. \& Cañasa, I., 2012. Assessment of compressed earth blocks made in Spain: International durability tests. Construction and Building Materials, 37, 738-745. https://doi. org/10.1016/j.conbuildmat.2012.08.019 
Jiménez, D. M. C. \& Guerrero, I. C., 2007. The selection of soils for unstabilised earth building: A normative review. Construction and Building Materials, 21,2, 237-251. https://doi.org/10.1016/j. conbuildmat.2005.08.006

Laga, P., Lowye, S. \& Geets, S., 2001. Paleogene and Neogene lithostratigraphic units (Belgium). In Bultynck, P. \& Dejonghe, L. (eds), Guide to a revised lithostratigraphic scale of Belgium. Geologica Belgica, 4/1-2, 135-152.

Laloux, M., Dejonghe, L., Ghysel, P. \& Hance, L., 1996. Carte géologique de Wallonie : Fléron - Verviers 42/7-8. 1/25 000. Namur, Ministère de la Région wallonne, Direction générale des ressources naturelles et de l'environnement, avec une notice explicative de $150 \mathrm{p}$.

Legrand R., 1968. Le Massif du Brabant. Mémoires pour servir à l'explication des cartes géologiques et minières de la Belgique, 9, $1-148$.

LOCI, 2016. Séminaire de la construction en terre crue. Communication presented at Raw Earth Week, Tournai, Belgium, April 11-15, 2016.

Maréchal, R., 1993. A new lithostratigraphic scale for the Palaeogene of Belgium. Bulletin de la société belge de géologie, 102, 215-229.

Maréchal, R. \& Laga, P., 1988. Voorstel lithostratigraphische indeling van het Paleogeen. Nationale Commissie voor Stratigrafie, Commissie Tertiair, Brussel, $207 \mathrm{p}$.

Marlière, R., 1954. Crétacé. In Fourmarier, P., (ed.), Prodrome d'une description géologique de la Belgique. Société géologique de Belgique, Liège, 417-444.

Maubeuge, P-L., 1954. Le Trias et le Jurassique du Sud-Est de la Belgique. In Fourmarier, P. (ed.), Prodrome d'une description géologique de la Belgique. Société géologique de Belgique, Liège, 385-416.

Moevus, M., Fontaine, L. \& Anger, R., 2012. Caractéristiques mécaniques, thermiques et hygrométriques du matériau terre crue : bilan de la littérature. Editions CRAterre éditions, Villefontaine, 877 p.

Morel, J C, Pkla, A, \& Walker, P., 2007. Compressive strength testing of compressed earth blocks. Construction and Building Materials, 21, 2, 303-309. https://doi.org/10.1016/j.conbuildmat.2005.08.021

National Commission for Stratigraphy Belgium (NCS), 2019. The National Commission for Stratigraphy in Belgium. https://ncs. naturalsciences.be, accessed 04/22/2019.

Nicaise, D. \& Dupuis, C., 1997. L'halloysite des crytokarsts néogenes de l'Entre-Sambre-et-Meuse et du Condroz (Belgique). Unpublished document, Région wallonne, $134 \mathrm{p}$.

Niroumand, H., Barcelo, J. A., Kibert, C. J. \& Saaly, M., 2017. Evaluation of Earth Building Tools in Construction (EBTC) in earth architecture and earth buildings. Renewable and Sustainable Energy Reviews, 70, 861-866. https://doi.org/10.1016/j.rser.2016.11.267

Peltier, R. \& Rumpler, A., 1959. Manuel du laboratoire routier. Dunod, Paris, $274 \mathrm{p}$.

Projet Terra incognita. 2014. Terra incognita : découvrir et préserver une Europe des architectures de terre. Lisbonne, Argumentum. http:// culture-terra-incognita.org/, accessed 24/10/2018.

Rekk, S., 2014. Méthodologie et essai de constitution de terroirs géochimiques : application aux céramiques communes d'ateliers du Nord de la Gaule. Unpublished PhD thesis. Université de Namur, Département de Géologie, Namur.

Rigassi, V., 1995. Blocs de terre comprimée, volume I. Manuel de production. Édidions CRAterre, Villefontaine, 104 p.

Riza, F.V., Rahman, I.A \& Zaidi, A.M.A., 2010. A brief review of compressed stabilized earth brick (CSEB). International Conference on Science and Social Research, Kuala Lumpur, 999-1004.

Robaszynski, F. Dhondt, A. \& Jagt, J., 2001. Cretaceous lithostratigraphic units (Belgium). In Bultynck, P. \& Dejonghe, L. (eds), Guide to a revised lithostratigraphic scale of Belgium. Geologica Belgica, 4/12, 121-134

Sitton, J. D., Zeinali, Y. \& Story, B. A., 2017. Rapid soil classification using artificial neural networks for use in constructing compressed earth blocks. Construction and Building Materials, 138, 214-221. https://doi.org/10.1016/j.conbuildmat.2017.02.006

Spagna, P., Yans, J., De Putter T., Hilde, V. \& Dupuis, C., 2006. Les ressources en matières argileuses de la Belgique : le point de la question en 2003. Mines et Carrières, 104, 36-43.

Spagna, P., Dupuis, C. \& Yans, J., 2008. Sedimentology of the Wealden clays in the Hautrage quarry. Memoirs of the Geological Survey of Belgium, 55, 35-44.
Steurbaut, E., 1998. High-resolution holostratigraphy of Middle Paleocene to Early Eocene strata in Belgium and adjacent areas. Palaeontographica, Abteilung A, 247, 91-156.

Steurbaut, E. \& King, C., 2017. The composite Kortrijk section (W Belgium): a key reference for mid-Ypresian (Early Eocene) stratigraphy in the southern North Sea Basin. Geologica Belgica, 20/3-4, 125-159. http://dx.doi.org/10.20341/gb.2017.008

Steurbaut, E., De Ceukelaire, M., Lanckacker T., Matthijs, J., Stassen, P., Van Baelen H. \& Vandenberghe, N., 2016. Lithostratigraphy Ieper Group. National Commission for Stratigraphy Belgium. http:// ncs.naturalsciences.be/paleogene-neogene/ieper-group, accessed 24/10/2018.

Tavernier R. \& Gulinck, M., 1947. Les roches argileuses de la Basse et de la Moyenne Belgique. In Centenaire de l'Association des Ingénieurs sortis de l'Ecole de Liège, Congrès 1947, Section Géologie, 277-281.

Trachte, S., 2012. Matériau, matière d'architecture soutenable : Choix responsable des matériaux de construction, pour une conception globale de l'architecture soutenable. Unpublished $\mathrm{PhD}$ thesis. Université catholique de Louvain, Faculté d'architecture, d'ingénierie architecturale et d'urbanisme, Louvain-la-Neuve, 394 p.

UNEP/UNECE, 2016. Global environment outlook: GEO-6 Assessment for the Pan-European region. Nairobi, United Nations Environment Program, $364 \mathrm{p}$.

Vandenberghe, N., 2017. Tectonic and climatic signals in the Oligocene sediments of the Southern North-Sea Basin. Geologica Belgica, 20/34, 105-123. http://dx.doi.org/10.20341/gb.2017.007

Vandenberghe N., Laenen B., Van Echelpoel E. \& Lagrou D., 1997. Cyclostratigraphy and climatic eustasy. Example of the Rupelian stratotype. Earth and Planetary Science, 325, 305-315. https://doi. org/10.1016/S1251-8050(97)81377-8

Vandenberghe, N., De Craen, M. \& Wouters, L., 2014. The Boom Clay geology from sedimentation to present-day occurrence. A review. Memoirs of the Geological Survey of Belgium, 60, $76 \mathrm{p}$.

Vergari A. \& Quinif Y., 1997. Les paléokarsts du Hainaut. Geodinamica Acta, 10, 4, 175-187. https://doi.org/10.1080/09853111.1997.11105 301

Voisin, L., 1995. Le kaolin en Ardenne. Bulletin de la société d'histoire naturelle des Ardennes, 85, 64-70.

Walker, P., 2000. Strength and durability testing of earth blocks. Paper presented at Proceedings of the 6th International Seminar on Structural Masonry for Developing Countries, Bangalore, India, 110-118.

Wouters, L. \& Vandenberghe N., 1994. Géologie de la Campine - Essai de synthèse. ONDRAF/NIRAS, Bruxelles, 208 p.

Yans J., Spagna P., Foucher J.-C., Perruchot A., Streel M., Beaunier P., Robaszynski F. \& Dupuis C., 2002. Multidisciplinary study of the Wealden deposits of the Mons Basin (Belgium): a progress report. Aardkundige Mededelingen, 12, 39-42.

Manuscript received 18.07.2018, accepted in revised form 31.01.2019, available online 03.12.2019. 


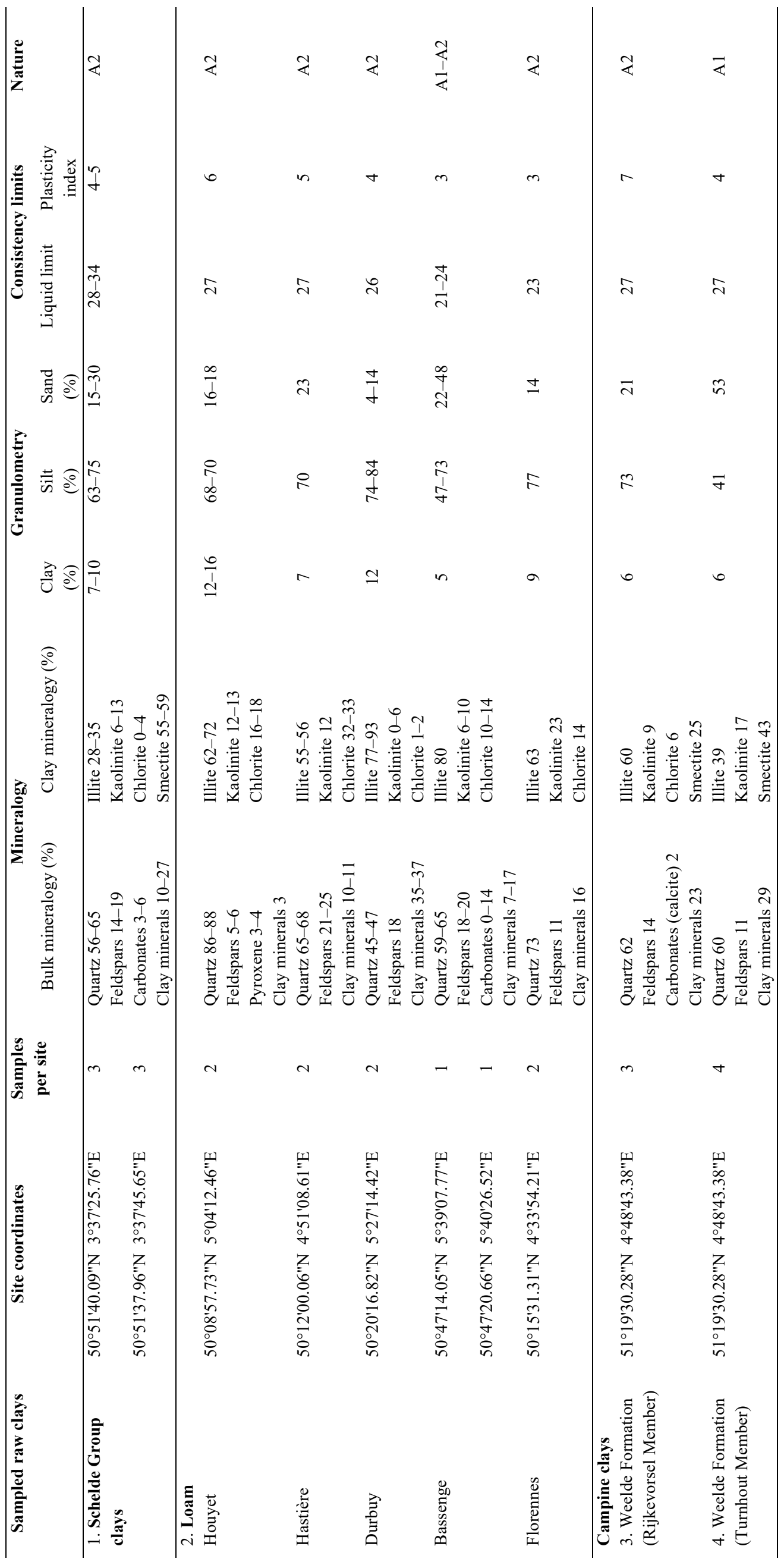




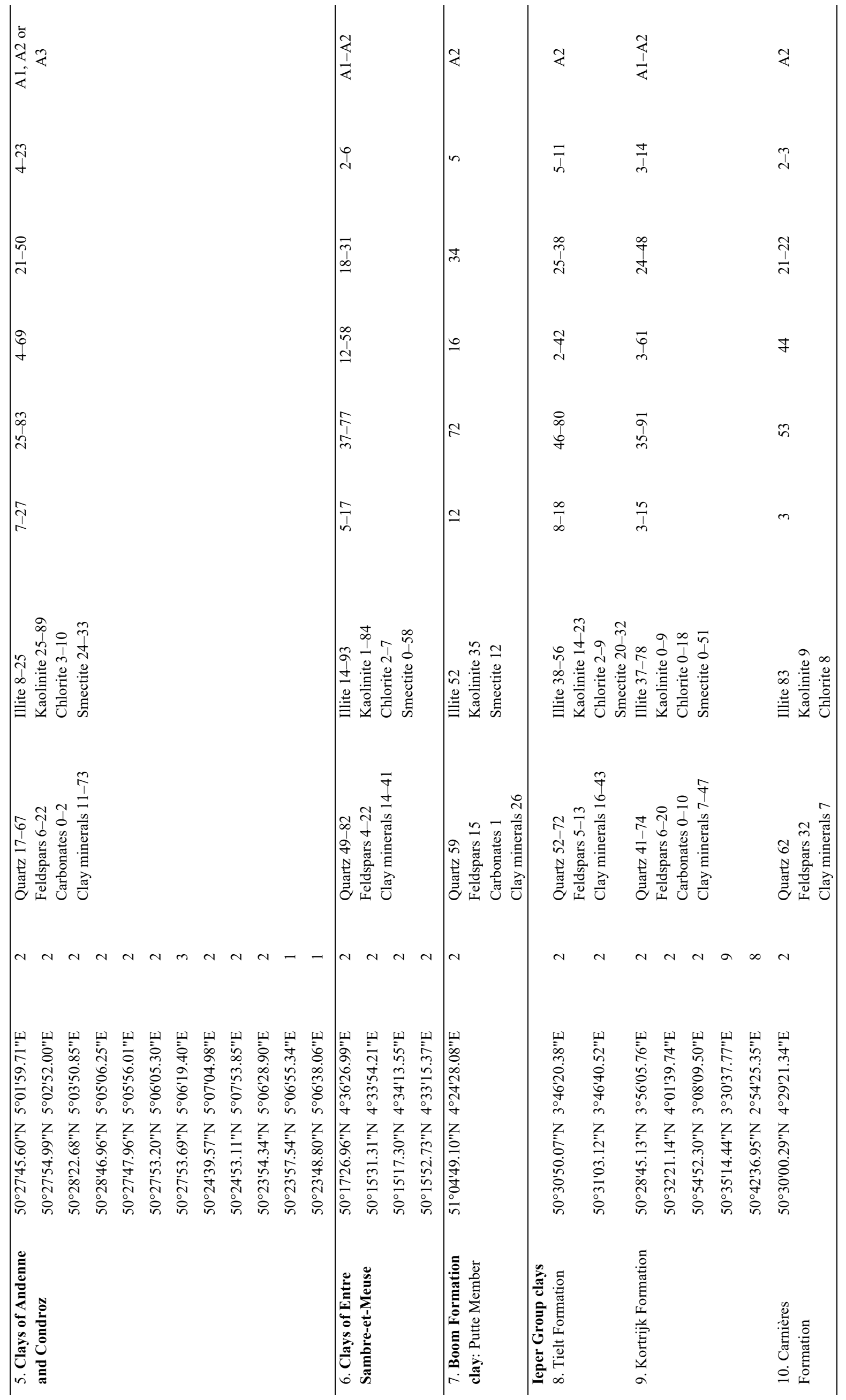




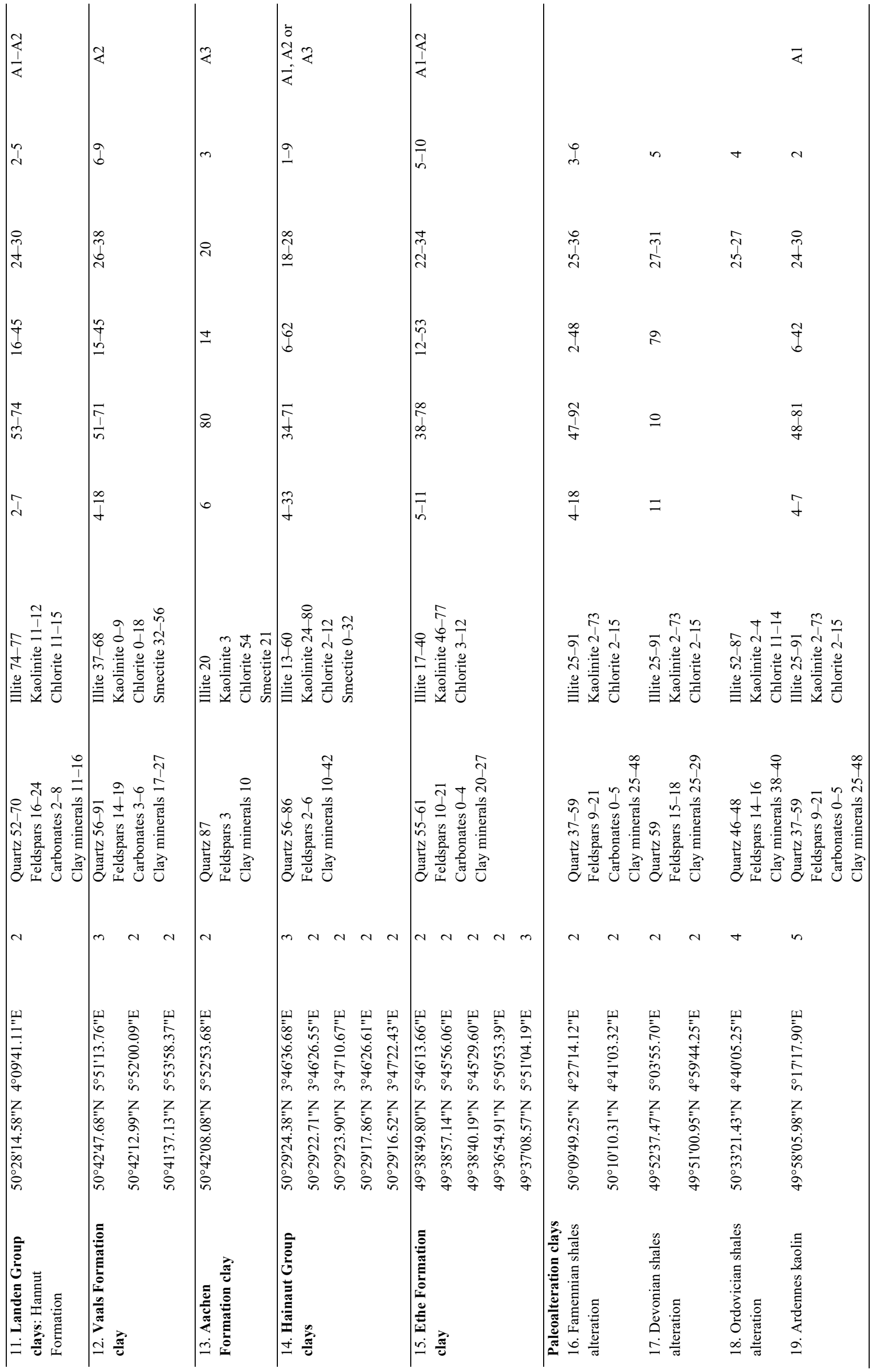

